\title{
MICROWAVE DRYING OF SPINACIA OLERACEA
}

\author{
S. Sharada ${ }^{1}$ \\ ${ }^{1}$ Assistant Professor, Department of Chemical Engineering, JNTUACEA, Ananthapur \\ sharada01s@gmail.com
}

\begin{abstract}
Fresh spinach leaves with $50 \mathrm{~g}$ weight were taken from the market and 9.86 moisture content on dry basis were dried in a microwave oven using four different microwave power levels ranging between 90 and $350 \mathrm{~W}$, until the moisture content fell down to 0.1 on dry basis. The drying processes were completed between 570 and 1350s depending on the microwave power level. Moisture ratio and drying rate were calculated. In this study the measured values of moisture ratio were compared with predicted values obtained from Newton, Henderson and Pabis, Midilli et al and pages thin layer drying semi empirical equations. On detailed study of the four model equations, Midilli et al. equation was found to be the best fit for the drying of spinach leaves by spinach leaves by using microwave oven. The fitness of these models was evaluated by using the reduced chi-square, root mean square error and modeling efficiency. The specific energy consumption to evaporate a unit mass of water from the product was also determined.
\end{abstract}

Keywords: Spinach Leaves, Moisture Content, Moisture Ratio, Drying rate and Micro wave. *** $*$

\section{INTRODUCTION}

Spinach is a cool season annual vegetable it is popular vegetable that is eaten raw, boiled or baked in to various dishes. Spinach is low in calories and good source of ascorbic acid. It hydro-soluble vitamin and more sensitive to heat, oxygen, light Different drying methods are used in the drying of fruits and vegetables. Hot air drying is the most common method in the drying of food stuffs. This method leads to serious injurious such as the worsening of taste, color and nutritional content of the product, decrease in density and water absorbance capacity due to long drying period and high temperature. The use of microwave rays in the drying of products has become important as it retains the nutritional values, color and taste. Distribution of heat is uniform to the material.

LI Yu et al [1] in the year 2010 reported on microwave drying of ilmenite. By experimental analysis Henderson-pabis index model was fit rather than Pages semi empirical model. Balaswamy et al [ 2] .In the year 2002 done the experiments on drying of wheat with the method domestic microwave and conventional microwave. On experimental analysis concluded that with conventional microwave notional values and proteins. A. Reyes et al [3] in the year 2006 conducted a comparative study of microwave assisted air drying or potato slices. The potato slices were dried in a tunnel drier, a conventional fluidized bed drier with application of microwaves. The main objective of their work were to determine the experimental conditions that maximize the drying time and improve the quality of dehydrated potato slices and to evaluate the models to fit the drying curves of potato slices. M.Zhang et al [4]. In the year 2006 conducted a research on trends in microwave related drying fruits and vegetables. This review has shown that microwave related combination provide unique opportunities in the development of advanced food drying technologies .Y.Soyal et al [5]. In the year 2006 conducted a research on microwave drying of parsley, the energy efficiency and specific energy consumption to evaporate the unit mass of water are calculated. Alibas ozkan et al [6]. In the year 2004 conducted research on the microwave drying characteristics of spinach Energy consumption, drying time and color criteria are studied in the paper.

\section{Materials and Methods:}

\subsection{Materials}

1) Fresh spinach leaves

2) Micro Wave oven

3) Electronic weighing balances

\subsection{Methods}

\subsubsection{Drying Equipment}

Drying treatment was performed in a distance digital microwave oven with technical features of $230 \mathrm{~V}, 50 \mathrm{~Hz}$ and $750 \mathrm{~W}$. the microwave oven has the capacity of operating at four different microwave stages, being 90, 160, 350 and $500 \mathrm{~W}$. The area on which microwave drying is carried out was $327 * 370 * 207 \mathrm{~mm}$ in size and consisted of a rotating glass plate with $280 \mathrm{~mm}$ diameter at the base oven. Glass plate rotates for $5 \mathrm{~min}^{-1}$ and the direction of $360^{\circ \mathrm{C}}$ rotation can be changed by pressing the on/off button. Time adjustment is done with the aid of a digital clock located on the oven. 


\subsubsection{Drying Method}

Drying trial was carried out at four different microwave generation power being 500, 350, 160 and $90 \mathrm{~W}$. the spinach leaves to be dried were $50( \pm 0.09) \mathrm{g}$ in weight and selected from uniform and healthy plants. Three different drying trials were conducted at each microwave averaged and the drying parameters were determined. rotating glass plate was removed from the oven periodically i,e every 30 seconds during the drying period and the moisture loss was determined by weighing the plate using digital balance with $0.01 \mathrm{~g}$ precision was continued until the moisture content of spinach fell down to $(0.1 \pm 0.009)$ on the dry basis.

\subsection{Drying Curves}

Moisture content time diagram of spinach along the drying period on dry basis is plotted. A reduction in drying time occurred with the increasing moisture power level. The quantities of moisture removal from the material in every 30 sec. time period is plotted. The maximum value of moisture removed at regular intervals of time can be evaluated. The drying rates of the spinach leaves at different microwave power levels against moisture content are plotted on the dry basis. The energy consumption during the drying of spinach leaves are plotted. The power for which maximum specific energy consumption can be obtained

\subsection{Statistical Analysis}

The root mean square error $\mathrm{E}_{\mathrm{RMS}}$ and the modeling efficiency $\eta_{\mathrm{m}}$ were used as the primary criterion to select the best equation expressing the microwave drying curves of spinach. The $\mathrm{E}_{\mathrm{RMS}}$ gives the deviation between the predicted and exponential values. The lower values ability of the $E_{R M S}$, the better the goodness of fit. The value for $\eta_{\mathrm{m}}$ on the other hand, determines the fitting ability of the equation and it is required to reach 1 for the best results. These statistical criterions can be calculated as follows.

$\mathrm{E}_{\mathrm{RMS}}=\left[\begin{array}{lllll}1 / \mathrm{N} & \left.\sum_{\mathrm{i}=1}^{\mathrm{N}}\left(\mathrm{M}_{\mathrm{R},}, \mathrm{Cal}, \mathrm{i}-\mathrm{M}_{\mathrm{R}}, \quad \exp , \quad \mathrm{i}\right)^{2}\right] & 0.5\end{array}\right.$ ..............................(1)

$\eta_{\mathrm{m}}=\sum_{\mathrm{i}=1}^{\mathrm{N}}\left(\mathrm{M}_{\mathrm{R}, \mathrm{Cal}, \mathrm{i}}-\mathrm{M}_{\mathrm{R}, \exp , \text { avg, } \mathrm{i}}\right)^{2}-\sum_{\mathrm{i}=1}^{\mathrm{N}}\left(\mathrm{M}_{\mathrm{R}, \mathrm{Cal}, \mathrm{i}}-\mathrm{M}_{\mathrm{R}, \mathrm{i}}\right.$ $\exp , \quad \mathrm{i})^{2} / \sum_{\mathrm{i}=1}^{\mathrm{N}}\left(\mathrm{M}_{\mathrm{R}}, \mathrm{Cal}, \mathrm{i}-\mathrm{M}_{\mathrm{R}} \text {, exp, avg, } \mathrm{i}\right)^{2}$

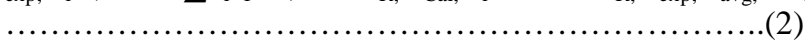

$\chi^{2}=\sum^{N}{ }_{i=1}\left(M_{R, C a l, i}-M_{R, \exp , i}\right)^{2} / N-Z$

The fitness of the tested mathematical models to the experimental data was evaluated with the coefficient of determination $\left(\mathrm{R}^{2}\right)$, reduced Chi-square $\left(\chi^{2}\right)$ and the root mean square error (RMSE). The higher the $\mathrm{R}^{2}$ values and the lower the $\chi^{2}$ and RMSE values, the better is the fitness. Where $M_{R}$, exp, I is the $i^{\text {th }}$ experimental moisture ratio, $M_{R, \exp , \mathrm{I}}$ is the $\mathrm{i}^{\text {th }}$ predicted moisture ratio, $\mathrm{N}$ is the number of observations and $\mathrm{Z}$ is the number of constants in the drying model.

\subsection{Determination of Specific Energy Consumption}

Effect of material load on the energy efficiency of microwave drying at microwave power cycle of $9 \mathrm{~s}$ on $9 \mathrm{~s}$ off at $350 \mathrm{~W}$ was evaluated by two different efficiency indices as microwave drying efficiency in \% and specific energy consumption in MJ $\mathrm{kg}^{-1}\left[\mathrm{H}_{2} \mathrm{O}\right]$. The microwave drying was calculated as the ratio of heat energy utilized for evaporating water from the sample to heat supplied by the microwave oven. The cumulative drying efficiency values were calculated as the average energy consumption for water evaporation divided by the supplied microwave energy in the total power on time ton in $S$;

Where $\mathrm{m}_{\mathrm{w}}$ is the mass of evaporated water in $\mathrm{kg} ; \mathrm{P}$ is the average microwave power in $\mathrm{W}$ and $\mathrm{t}_{\mathrm{on}}$ is the time interval in s. the specific energy consumption was calculated as the energy needed to evaporate a unit mass of water.

$\mathrm{Q}_{\mathrm{s}}=\mathrm{t}_{\mathrm{on}} * \mathrm{P} * 10^{-6} / \mathrm{m}_{\mathrm{w}}$

$\mathrm{Q}_{\mathrm{s}}$ is the specific energy consumption to evaporate a unit mass of water from the product in $\mathrm{MJKg}^{-1}\left[\mathrm{H}_{2} \mathrm{O}\right]$.

\subsection{Data Analysis}

Non-linear regression analysis was performed and the parameter $\mathrm{k}$ and $\mathrm{n}$ were estimated. This analysis is used for models page's equation, newton's equation, Henderson and pabis and Midilli et al. equations. The results include standard error of estimate and coefficient of regression.

\subsection{Drying Curves}

Moisture ratio-time diagram of spinach along the drying period on dry basis is given in fi.4.1. As seen in fig 4.1, a reduction in drying time occurred with the increasing microwave power level. The time required for the lowering of moisture content of spinach levels to 0.1 level, from 9.86 on dry basis varied between 570 and $1350 \mathrm{~S}$ depending on the microwave power level. A marked decline was noted in the drying period of leaves with the increasing microwave power level. The drying time obtained in the drying process using $90 \mathrm{~W}$ microwave power levels was 2.86 times longer than those in $350 \mathrm{~W}$.

During the drying of $50 \mathrm{~g}$ spinach leaves at four different microwave power, a total of $44.5 \mathrm{~g}$ of weight loss occurred from each drying sample. The quantities of moisture removed from the material in every 30 s time period of drying cycle at four different microwave power levels are given in fig.4.2. Maximum value of moisture removed from the material at 350 $\mathrm{W}$ microwave power $(4.69 \mathrm{~g})$ was obtained between 220 and $250 \mathrm{~s}$ of the drying period. About $60 \%$ of the drying process was completed in the $220^{\text {th }}$ second when the maximum evaporation rate was recorded. The value of maximum evaporation between $240^{\text {th }}$ and $270^{\text {th }}$ seconds of the drying 
period at $90 \mathrm{w}$ microwave powers was determined as $0.66 \mathrm{~g}$. At this point, $7.91 \%$ of the drying process was completed.

The drying rates obtained in unit time under different microwave power levels are given in fig.4.3. Depending on the drying conditions, average drying rates of spinach leaves ranged from 0.219 to $0.802 \mathrm{~kg}\left(\mathrm{H}_{2} \mathrm{O}\right) \mathrm{kg}^{1}$ (DM) $\mathrm{min}^{-1}$ for the output power between 90 and $350 \mathrm{~W}$, respectively. The moisture content of the material was very high during the initial phase of the drying which resulted in a higher absorption of microwave power and higher drying rates which resulted in higher moisture diffusion. As the drying progressed, the loss of the moisture in the product caused a decrease in the absorption of microwave power and resulted in a fall in the drying rate. The drying rates increased with the increasing microwave power levels. Therefore microwave power level has an important effect on drying rates.

The specific energy consumption values obtained in the drying trials carried out at four different microwave power levels. Fig.4.4.energy consumption at all levels within the power range $90 \mathrm{w}$ and $350 \mathrm{~W}$ in which the drying process lasted for $570-1350$ seconds. The drying energy consumption rates were determined as $3.26 \mathrm{MJkg}^{-1}\left[\mathrm{H}_{2} \mathrm{O}\right]$ and $2.7 \mathrm{MJkg}^{-1}\left[\mathrm{H}_{2} \mathrm{O}\right.$ ] for the power values of $160 \mathrm{~W}$ with drying period of $1020 \mathrm{~S}$ and $90 \mathrm{~W}$ with drying of $1350 \mathrm{~S}$. as result, the energy consumption in the drying processes carried out at low microwave power levels yielded longer drying period.

\subsection{Modeling Drying Data}

Microwave drying kinetics of spinach leaves were described using the drying data. Non-linear regression technique was used to estimate the parameters $\mathrm{k}$ and $\mathrm{n}$ of semi-empirical Newton, Henderson and Pabis, Pages and Midilli equations. MATLAB coding was done to predict moisture ratio, $\mathrm{k}$ and $\mathrm{n}$ values.

From the above data we can determine the best fir for micro oven drying of spinach leaves. The Midilli et al. model was the best fit with all the data points with efficiency more than $99 \%$ for all the input powers. The lower the values of $E_{\mathrm{rms}}$ the better the goodness of fit The values of efficiency on the other hand, determine the fitting ability of the equation and it is required to reach 1 for the best results.

The established model was validated by comparing the predicted moisture ratios to the experimental values from all the drying experiments. The predicted data banded over the straight line of the ratio $1: 1$, with a value for the determine coefficient $\mathrm{R}^{2}$ of 0.995 fig. 4.5 . The linear regression of these results gave the expression as

$$
\mathrm{M}_{\mathrm{R}, \mathrm{Cal}}=0.9951 \mathrm{M}_{\mathrm{R}, \operatorname{Exp}}+0.0024 \ldots
$$

\subsection{Results of Statistical analysis}

Comparison of predicted and experimental moisture ratio: In this experiment the primary criteria for a particular mathematical model to be the best fit, we should have the root mean square root values of the model at different powers very low when compared to other models .another criteria for the models to be the best fit is that we should have very lowered chi-sqaure values when compared to the other models. The modeling efficiency of the model on the other hand should reach a value of one, inorder to express the model the model for the best fit. Since from our observations as the values of the root mean square error, reduced chi-square are very low and the modeling efficiency nearly reaching 1 for the midilli et al.model we can conclude it is the best fit.

Using MATLAB for solving model equations the values of the constants $\mathrm{k}, \mathrm{n}$ and a are determined for various values of the power input. The results are shown in table 4.2.by comparing all the values from the table 4.4, 4.5.it was concluded that midilli et al. model is the best fit for drying at power $240 \mathrm{~W}$.

\section{CONCLUSIONS}

Based on the result of the study, the midilli et al. model gave the best fit for all experimental data points with values of modeling efficiency greater than 0.9974 and the root mean square of lower than 0.017 . A reduction in drying time occurred with the increasing microwave power level. The value of the drying coefficient $\mathrm{k}$ value increased with increase power. The drying efficiency of spinach for different models is ranging between 0.90-0.99.

\begin{tabular}{|c|c|}
\hline Power (W) & $\begin{array}{l}\text { Qs ( Specific energy consumption ) } \mathrm{MJkg}^{-} \\
{ }^{1}\left[\mathrm{H}_{2} \mathrm{O}\right]\end{array}$ \\
\hline 340 & 4.33 \\
\hline 240 & 4 \\
\hline 160 & 3.626 \\
\hline 90 & 2.7 \\
\hline
\end{tabular}

Table 4.2 Values of constants $\mathrm{k}, \mathrm{n}$ and a at different values of power input.

\begin{tabular}{|l|l|l|l|l|l|}
\hline Model equation & \multicolumn{1}{|l|}{$\mathrm{K}\left(\mathrm{min}^{-1}\right)$} & $\mathrm{n}$ & $\mathrm{a}$ & $\mathrm{B}$ \\
\hline \multicolumn{7}{|c|}{ Power: 350W } & - & - \\
\hline Newton and & 0.8167 & 0.2476 & - & - & - \\
\hline $\begin{array}{l}\text { Henderson } \\
\text { Pabis }\end{array}$ & 1.379 & - & \\
\hline
\end{tabular}




\begin{tabular}{|c|c|c|c|c|}
\hline Pages & 0.0209 & 2.3189 & - & - \\
\hline Midilli et al. & 0.0174 & 2.297 & 0.9174 & 0.08 \\
\hline \multicolumn{5}{|l|}{ Power: $240 \mathrm{~W}$} \\
\hline Newton & 0.1095 & - & - & - \\
\hline $\begin{array}{l}\text { Henderson and } \\
\text { Pabis }\end{array}$ & 0.1374 & 1.2452 & - & - \\
\hline Pages & 0.014 & 1.9281 & - & - \\
\hline Midilli et al. & 0.0190 & 1.2117 & 1.002 & -0.087 \\
\hline \multicolumn{5}{|l|}{ Power: $160 \mathrm{~W}$} \\
\hline Newton & 0.155 & - & - & - \\
\hline $\begin{array}{l}\text { Henderson and } \\
\text { Pabis }\end{array}$ & 0.929 & 1.282 & - & - \\
\hline Pages & 0.0197 & 2.0931 & - & - \\
\hline Midilli et al. & 0.019 & 2.0312 & 0.9815 & -0.087 \\
\hline \multicolumn{5}{|l|}{ Power: 90W } \\
\hline Newton & 0.0858 & - & - & - \\
\hline $\begin{array}{l}\text { Henderson and } \\
\text { Pabis }\end{array}$ & 0.1047 & 1.2117 & - & - \\
\hline Pages & 0.0116 & 1.807 & - & - \\
\hline Midilli et al. & 0.0166 & 1.5314 & 1.002 & -0.00767 \\
\hline
\end{tabular}

Table.4.3. comparison of experimental moisture rations values with predicted values at $350 \mathrm{~W}$.

\begin{tabular}{|l|l|l|l|l|l|}
\hline S.No & Newton model & $\begin{array}{l}\text { Henderson and } \\
\text { pabis Model }\end{array}$ & Pages Model & Midilli et al & $\begin{array}{l}\text { Experimental } \\
\text { values }\end{array}$ \\
\hline 1 & 0.91 & 1.1556 & 0.9958 & 0.9636 & 1 \\
\hline 2 & 0.828 & 1.021 & 0.9794 & 0.9458 & 0.952 \\
\hline 3 & 0.7535 & 0.9021 & 0.948 & 0.9162 & 0.906 \\
\hline 4 & 0.6856 & 0.7971 & 0.9011 & 0.8741 & 0.857 \\
\hline 5 & 0.6239 & 0.7043 & 0.8397 & 0.82 & 0.803 \\
\hline 6 & 0.5677 & 0.6222 & 0.766 & 0.7553 & 0.725 \\
\hline 7 & 0.5176 & 0.5498 & 0.6831 & 0.6819 & 0.66 \\
\hline 8 & 0.4701 & 0.4858 & 0.5949 & 0.6025 & 0.61 \\
\hline 9 & 0.4277 & 0.4292 & 0.5053 & 0.5199 & 0.548 \\
\hline 10 & 0.3892 & 0.3792 & 0.4183 & 0.4371 & 0.467 \\
\hline 11 & 0.3542 & 0.335 & 0.3372 & 0.3566 & 0.394 \\
\hline 12 & 0.3223 & 0.2960 & 0.2645 & 0.2809 & 0.291 \\
\hline 13 & 0.2933 & 0.2616 & 0.2016 & 0.2118 & 0.199 \\
\hline 14 & 0.2669 & 0.2311 & 0.1493 & 0.1503 & 0.122 \\
\hline 15 & 0.2428 & 0.2042 & 0.1074 & 0.0972 & 0.067 \\
\hline 16 & 0.2210 & 0.1594 & 0.0749 & 0.0523 & 0.025 \\
\hline 17 & 0.2011 & 0.1408 & 0.0506 & 0.0153 & 0.0026 \\
\hline 18 & 0.183 & 0.1244 & 0.332 & -0.0147 & 0 \\
\hline 19 & 0.1665 & 0.118 & 0.0211 & -0.0385 & 0 \\
\hline
\end{tabular}

Table.4.4. comparison of experimental moisture rations values with predicted values at $240 \mathrm{~W}$.

\begin{tabular}{|l|l|l|l|l|l|}
\hline S.No & Newton model & $\begin{array}{l}\text { Henderson and } \\
\text { pabis Model }\end{array}$ & Pages Model & Midilli et al & $\begin{array}{l}\text { Experimental } \\
\text { values }\end{array}$ \\
\hline 1 & 0.9252 & 1.9591 & 0.9954 & 0.9743 & 1 \\
\hline 2 & 0.8560 & 1.0494 & 0.9805 & 0.9579 & 0.974 \\
\hline 3 & 0.7919 & 0.9502 & 0.9950 & 0.9322 & 0.917 \\
\hline
\end{tabular}




\begin{tabular}{|l|l|l|l|l|l|}
\hline 4 & 0.7327 & 0.8603 & 0.9193 & 0.8978 & 0.879 \\
\hline 5 & 0.6779 & 0.7789 & 0.8744 & 0.8557 & 0.846 \\
\hline 6 & 0.6279 & 0.7052 & 0.8216 & 0.8068 & 0.791 \\
\hline 7 & 0.5802 & 0.6385 & 0.7623 & 0.7524 & 0.739 \\
\hline 8 & 0.5368 & 0.5781 & 0.6984 & 0.6938 & 0.694 \\
\hline 9 & 0.4967 & 0.5234 & 0.6317 & 0.6325 & 0.631 \\
\hline 10 & 0.4595 & 0.4739 & 0.5641 & 0.5697 & 0.586 \\
\hline 11 & 0.4251 & 0.4290 & 0.4971 & 0.5068 & 0.519 \\
\hline 12 & 0.3933 & 0.3884 & 0.4323 & 0.4451 & 0.449 \\
\hline 13 & 0.3639 & 0.3517 & 0.3710 & 0.3854 & 0.399 \\
\hline 14 & 0.3367 & 0.3184 & 0.3141 & 0.3287 & 0.335 \\
\hline 15 & 0.3115 & 0.2883 & 0.2624 & 0.2757 & 0.275 \\
\hline 16 & 0.2882 & 0.2610 & 0.2162 & 0.2268 & 0.236 \\
\hline 17 & 0.2666 & 0.2363 & 0.1758 & 0.1824 & 0.174 \\
\hline 18 & 0.2467 & 0.2140 & 0.1409 & 0.1424 & 0.133 \\
\hline 19 & 0.2282 & 0.1937 & 0.1114 & 0.1070 & 0.0963 \\
\hline 20 & 0.2111 & 0.1754 & 0.086 & 0.0760 & 0.055 \\
\hline 21 & 0.1953 & 0.1588 & 0.066 & 0.049 & 0.0340 \\
\hline 22 & 0.1807 & 0.1438 & 0.0507 & 0.0259 & 0.025 \\
\hline 23 & 0.1672 & 0.1302 & 0.0379 & 0.0061 & 0.003 \\
\hline 24 & 0.1547 & 0.1179 & 0.0279 & -0.0106 & 0 \\
\hline 25 & 0.1431 & 0.1067 & 0.0203 & -0.0246 & 0 \\
\hline
\end{tabular}

Table.4.5. comparing of predicted and experimental moisture ratio values at $160 \mathrm{~W}$.

\begin{tabular}{|l|l|l|l|l|l|}
\hline S.No & Newton model & $\begin{array}{l}\text { Henderson and } \\
\text { pabis Model }\end{array}$ & Pages M odel & Midilli et al & $\begin{array}{l}\text { Experimental } \\
\text { values }\end{array}$ \\
\hline 1 & 0.947 & 1.1625 & 0.9963 & 1.002 & 1 \\
\hline 2 & 0.8963 & 1.0853 & 0.9861 & 0.9823 & 0.989 \\
\hline 3 & 0.8485 & 1.0233 & 0.9698 & 0.9592 & 0.967 \\
\hline 4 & 0.8033 & 0.9460 & 0.9481 & 0.9321 & 0.928 \\
\hline 5 & 0.7605 & 0.8832 & 0.9213 & 0.9061 & 0.889 \\
\hline 6 & 0.7199 & 0.8245 & 0.8900 & 0.8684 & 0.868 \\
\hline 7 & 0.6816 & 0.7698 & 0.8548 & 0.8328 & 0.834 \\
\hline 8 & 0.6452 & 0.7187 & 0.8163 & 0.7955 & 0.796 \\
\hline 9 & 0.6190 & 0.6710 & 0.7751 & 0.7568 & 0.757 \\
\hline 10 & 0.5783 & 0.6264 & 0.7319 & 0.7171 & 0.718 \\
\hline 11 & 0.5474 & 0.5848 & 0.6873 & 0.6768 & 0.684 \\
\hline 12 & 0.5183 & 0.5460 & 0.6417 & 0.6361 & 0.633 \\
\hline 13 & 0.4909 & 0.5097 & 0.5959 & 0.5953 & 0.591 \\
\hline 14 & 0.4645 & 0.4759 & 0.5564 & 0.5548 & 0.542 \\
\hline 15 & 0.4398 & 0.444 & 0.5056 & 0.5174 & 0.503 \\
\hline 16 & 0.4163 & 0.4148 & 0.4618 & 0.4752 & 0.479 \\
\hline 17 & 0.3942 & 0.3872 & 0.4197 & 0.4365 & 0.436 \\
\hline 18 & 0.3731 & 0.3615 & 0.3793 & 0.3988 & 0.388 \\
\hline 19 & 0.3533 & 0.3375 & 0.3410 & 0.3621 & 0.363 \\
\hline 20 & 0.3344 & 0.3151 & 0.3049 & 0.3266 & 0.344 \\
\hline 21 & 0.3166 & 0.2942 & 0.2712 & 0.2924 & 0.326 \\
\hline 22 & 0.2997 & 0.2747 & 0.2399 & 0.2595 & 0.290 \\
\hline 23 & 0.2838 & 0.2564 & 0.2119 & 0.2279 & 0.244 \\
\hline 24 & 0.2686 & 0.2394 & 0.1849 & 0.1978 & 0.187 \\
\hline
\end{tabular}




\begin{tabular}{|l|l|l|l|l|l|}
\hline 25 & 0.2543 & 0.3335 & 0.1640 & 0.1690 & 0.182 \\
\hline 26 & 0.2408 & 0.2087 & 0.1395 & 0.1416 & 0.156 \\
\hline 27 & 0.2279 & 0.1948 & 0.1202 & 0.1157 & 0.103 \\
\hline 28 & 0.2158 & 0.1818 & 0.1031 & 0.0911 & 0.076 \\
\hline 29 & 0.2043 & 0.1696 & 0.0879 & 0.0678 & 0.051 \\
\hline 30 & 0.1943 & 0.1585 & 0.0746 & 0.0459 & 0.030 \\
\hline 31 & 0.1831 & 0.1480 & 0.0630 & 0.0252 & 0.0143 \\
\hline 32 & 0.1733 & 0.1382 & 0.0529 & 0.0057 & 0.0054 \\
\hline 33 & 0.1611 & 0.1290 & 0.0442 & -0.0126 & 0 \\
\hline 34 & 0.1154 & 0.1204 & 0.0367 & -0.0299 & 0 \\
\hline
\end{tabular}

Table.4.6.Root mean square error and chi-square values for different models at different powers

\begin{tabular}{|l|l|l|l|l|l|}
\hline Power & ------ & $350 \mathrm{~W}$ & $240 \mathrm{~W}$ & $160 \mathrm{~W}$ & $90 \mathrm{~W}$ \\
\hline Newton Model & RMSE & 0.142 & 0.642 & 0.876 & 0.973 \\
\hline & $\mathrm{X}^{2}$ & 0.214 & 0.165 & 0.123 & 0.043 \\
\hline Page Model & RMSE & 0.0362 & 0.0362 & 0.0362 & 0.0356 \\
\hline & $\mathrm{X}^{2}$ & 0.0033 & 0.00086 & 0.00012 & 0.0004 \\
\hline $\begin{array}{l}\text { Henderson } \\
\text { Model }\end{array}$ & RMSE & 0.1088 & 0.092 & 0.100 & 0.079 \\
\hline & $\mathrm{X}^{2}$ & 0.01246 & 0.01039 & 0.0037 & 0.005 \\
\hline $\begin{array}{l}\text { Midilli et al. } \\
\text { Model }\end{array}$ & RMSE & 0.05756 & 0.0052 & 0.0046 & 0.0012 \\
\hline & $\mathrm{X}^{2}$ & 0.00378 & 0.00213 & 0.00157 & 0.00097 \\
\hline
\end{tabular}

\section{NOMENCLATURE}

$\mathrm{k}$ - Drying coefficient $\left(\mathrm{min}^{-1}\right)$

$\mathrm{db}-$ Dry basis ( kg moisture $)(\mathrm{kg} \mathrm{DM})^{-1}$

$\mathrm{n}-$ Exponential constant

$\mathrm{M}_{\mathrm{R}}$ - Moisture content $\mathrm{kg}\left[\mathrm{H}_{2} \mathrm{O}\right] \mathrm{kg}^{-1}$ [ DM]

$\mathrm{X}_{\mathrm{e}}$ - initial moisture content $\mathrm{kg}\left[\mathrm{H}_{2} \mathrm{O}\right] \mathrm{kg}^{-1}$ [ DM]

$\mathrm{R}^{2}-$ Co-efficient of determination

$\mathrm{N}$ - Number of observations

a - Coefficient constant

b - Coefficient constant

$\mathrm{Q}_{\mathrm{s}}$ - Specific energy of consumption $\left(\mathrm{MJkg}^{-1}\right)$

$\mathrm{M}_{\mathrm{w}}-$ mass of evaporated water $(\mathrm{kg})$

$\mathrm{P}$ - Average microwave power ( W)

$\mathrm{t}_{\mathrm{on}}-$ Total power on time $(\min )$

$\eta-$ Efficiency of modeling

$\chi$ - Chi-square

$\lambda$ - Latent heat of vaporization $\left(\mathrm{kJkg}^{-1}\right)$

\section{REFERENCES}

[1]. Yu LI, Ying LEI, Li-bo ZHANG, Jin- hui PENG, Changlong LI. Microwave drying characteristics and kinetics of ilmenite. Key Laboratory of Unconventional Metallurgy, Ministry of Education, Faculty of Metallurgical and Energy Engineering, Kunming University of Science and Technology, Kunming 650093, China.

[2]. S. G.Walde, K.BalaSwamy, V Velu, D.G Rao. Microwave drying and grinding characteristics of wheat. Central Food
Technological Research Institute, Resource Centre, Hyderabad , India.

[3]. A. Reyes, S. Ceron, R. Zuniya, P. Moyano ( 2006 ), A comparative study of microwave assisted air drying of potato slices. Journal of biosystems Engineering Research, 64 (1), 61-69

[4]. M.zhang, J. Tang, A.S mujumdar and S.Wang. (2006). Trends in microwave related drying of fruits and vegetables. Food science and Technology 17, 524-535

[5]. Y. Soyasol, S. oztekin, O.Eren ( 2006 ). Microwave Drying of parsley: Modelling, Kinetics and Energy Aspects. Biosystems Engineering 93 (4), 403-413.

[6]. I. Alibas Ozkan, B. Akbudak (2007). Microwave drying characteristics of spinach Journal of Food process Engineering, 17, 353-363. 